\title{
Elmada kurşuni küfe neden olan Botrytis cinerea'ya karşı boraksın etkisi
}

\author{
Perizat Coroeva $^{1}$ (iD) , İsmail Erper ${ }^{1,2 *}$ (i)
}

\begin{abstract}
ÖZET
Botrytis cinerea'nın neden olduğu kurşuni küf, elmaların hasat sonrası en önemli hastalıklardan biridir. $\mathrm{Bu}$ çalışmada, boraks $\left(\mathrm{Na}_{2} \mathrm{~B}_{4} \mathrm{O}_{7}\right)$ tuzunun $B$. cinerea'ya karşı etkinliği hem in vitro hem de in vivo'da değerlendirilmiştir. In vitro testler artan boraks konsantrasyonlarının $B$. cinerea'nın misel gelişimi, spor çimlenmesi ve çim tüpü uzaması üzerindeki engelleyici etkileri arasındaki farklılığın istatistiksel olarak önemli olduğunu göstermiştir $(P<0.05)$. Ayrıca misel gelişimi, spor çimlenmesi ve çim tüpü uzaması sırasıyla $\% 2.0, \% 1.0$ ve $\% 1.0$ boraks konsantrasyonlarında tamamen engellenmiştir. Öte yandan boraksın \%1.0 ve \%2.0 konsantrasyonlarının fungus misel gelişimi üzerine engelleyici etkileri arasında hiçbir önemli farklılık gözlenmemiştir $(P<0.05)$. Boraksın $\mathrm{EC}_{50}$, MIC ve MFC değerleri sırasıly \%0.263, $\% 1.0$ ve \% 1.0 olarak belirlenmiştir. In vivo denemeler hem koruyucu hem de tedavi edici boraks uygulamalarının kurşuni küfün hastalık gelişimini kontrole kıyasla önemli oranda azalttığını göstermiştir $(P<0.05)$. Genel olarak hastalık gelişimine karşı koruyucu uygulamaların tedavi edici uygulamalardan daha üstün olduğu ve \%3.0 boraks konsantrasyonunda, her iki uygulamada hastalık gelişiminin sırasıyla \%85.69 ve \%63.16 oranında azaldığı tespit edilmiştir. Sonuç olarak, çalışma bulguları, elma kurşuni küfünü kontrol etmek için boraks tuzunun kullanılabileceğini göstermektedir.
\end{abstract}

MAKALE
GEÇMIŞİ
Geliş
1 Eylül 2021
Kabul
26 Ekim 2021

ANAHTAR

KELIMMELER

Malus $\times$ domestica, hasat sonu,

kurşuni küf, sodyum tetraborat, alternatif mücadele

\section{The effect of borax against Botrytis cinerea, the casual agent grey mold on apple}

\begin{abstract}
Grey mold caused by Botrytis cinerea is one of the most important post-harvest diseases of apples. In this study, the efficacy of borax $\left(\mathrm{Na}_{2} \mathrm{~B}_{4} \mathrm{O}_{7}\right)$ salt against $B$. cinerea was evaluated in in vitro and in vivo. In vitro tests showed that the difference between the inhibitory effects of increasing borax concentrations on the mycelial growth, spore germination and germ tube elongation of $B$. cinerea was statistically significant $(P<0.05)$. Moreover, mycelial growth, spore germination and germ tube elongation were completely inhibited at $2.0 \%, 1.0 \%$ and $1.0 \%$ borax concentrations, respectively. On the other hand, no significant difference was observed between the inhibitory effects of $1 \%$ and $2 \%$ concentrations of borax on the mycelial growth $(P<0.05)$. The $\mathrm{EC}_{50}$, MIC and MFC values were $0.263 \%, 1.0 \%$ and $1.0 \%$, respectively. In vivo experiments have shown that both protective and curative borax applications significantly reduce the disease development of grey mold compared to control. In general, it was determined that the protective applications against the disease development were superior to the curative applications, and the disease development was reduced by $85.69 \%$ and $63.16 \%$, respectively, for both applications at $3 \%$ borax concentration. In conclusion, the study findings suggest that borax salt can be used to control apple grey mold.
\end{abstract}

\footnotetext{
${ }^{1}$ Kırgızistan-Türkiye Manas Üniversitesi, Ziraat Fakültesi, Bitki Koruma Bölümü, Bişkek / Kırgızistan

2 Ondokuz Mayıs Üniversitesi, Ziraat Fakültesi, Bitki Koruma Bölümü, Atakum, Samsun / Türkiye

*Corresponding Author: İsmail ERPER, e-mail: ismailer@omu.edu.tr; ismail.erper@manas.edu.kg
}

\section{ARTICLE HISTORY \\ Received \\ 1 September 2021 \\ Accepted}

26 October 2021

\section{KEY WORDS}

Malus $\times$ domestica, postharvest, grey mold, sodium tetraborate, alternative control 


\section{Giriş}

Elma (Malus $\times$ domestica Borkh.) Kırgızistan’da yetiştirilen önemli meyve türlerinden biri olup, üretim miktarı bakımından 27.437 ha alanda yıllık 151.207 ton ile ilk sırada yer almaktadır [7]. Kırgızistan'da elma üretimi tüm bölgelerde yapılmasına rağmen, en fazla üretim Isık-Göl, Osh ve Çüy bölgelerinde yapılmaktadır [2].

Tarımsal ürünlerde hasat öncesi görülen hastalıkların yanında, hasat sonrasında biyotik ve abiyotik faktörlerin neden olduğu hastalıklar ürünlerin hasadı, paketlenmesi, taşınması ve depolanması aşamalarında ortaya çıkabilmektedir. Sonuçta depolanan ürüne, çeşidine ve depo koşullarına bağlı olarak \%20-50 düzeyinde kayıplar görülebilmektedir [10]. Kırgızistan'da elma başta olmak üzere diğer önemli tarımsal ürünler için modern depolama ünitelerinin yaygın olmamasından dolayı depolanan ürünlerdeki kayıpların daha fazla olduğu bilinmektedir. Ürünlerin depolanması sürecinde özellikle fungal patojenlerin neden olduğu kayıplar son derece önemlidir. Elmalarda hasat sonrasında ortaya çıkan kayıplarda başta Botrytis cinerea ve Penicillium expansum olmak üzere Monilinia fructicola, Glomerella cingulata, Alternaria spp., Rhizopus stolonifer ve Mucor pyriformis türleri de ciddi ürün kayıplarına neden olabilmektedir [20]. Kurşuni küf etmeni B. cinerea üzüm, çilek, elma, kivi, domates, hıyar, biber ve süs bitkileri gibi 200'den fazla konukçu bitki türünün çiçek, yaprak, gövde, meyve ve diğer kısımlarına saldırarak hasat öncesi ve sonrası hastalıklara neden olmaktadır [5].

Dünyada hasat sonrası depolanan bazı ürünlerde fungal patojenlerin neden olduğu hastalıklara karşı sentetik fungisitler kullanılabilmektedir [29]. Ancak fungisitlerin insan ve çevre sağlığı üzerindeki olumsuz etkileri, bunlara karşı toplumsal farkındalığın oluşması ve $B$. cinerea gibi bazı patojenlerde fungisitlere karşı dayanıklılık probleminin ortaya çıkmasından dolayı, kimyasal mücadeleye alternatif mücadele yöntemlerinin geliştirilmesi ihtiyacı ortaya çıkmıştır [26]. Şimdiye kadar hasat sonu hastalıkların mücadelesinde fungisitlere alternatif olarak; biyolojik mücadele, sıcaklık uygulaması, organik, inorganik ve bazı bor tuz bileşiklerinin kullanımı, modifiye atmosfer ve ışınlama uygulamalarının tekli veya birlikte kullanım olanakları üzerinde çok sayıda çalışma yapılmıştır $[4 ; 27 ; 14 ; 16 ; 3 ; 6 ; 28]$.

Bazı bor tuz bileşiklerinin tarımsal üretim alanlarında gübre olarak kullanımının yanında, hasat sonu depolanan tarımsal ürünlerde önemli kayılara neden olan bazı fungal patojen (B. cinerea, Penicillium digitatum, P. italicum, P. expansum, M. fructigena vb.)'lere karş1 
antifungal etkileri yapılan değişik çalışmalarda tespit edilmiştir. Bu tuzlar fungal patojenlerin hücre zar yapısına zarar verip, sitoplazma içeriğinin boşalmasına ve sonuç olarak ölüme neden olmaktadır [15; 19]. Qin ve ark. [16] potasyum tetraboratın farklı konsantrasyonlarda üzümde $B$. cinerea'nın misel gelişimini (\%1.0), spor çimlenmesini (\%0.5) ve çim tüpü oluşumunu (\%1.0) tamamen engellediğini tespit etmişlerdir. Ayrıca bor uygulamasından sonra meyvelerde herhangi bir fitotoksisite rapor edilmemiştir. Benzer bir çalışmada Colletotrichum gloeosporioides'e karşı potasyum tetraboratın 20 $\mathrm{mM}$ konsantrasyonunun etmenin spor çimlenmesini \%72.4 düzeyinde ve mango meyveleri üzerinde lezyon oluşumunun ise \%46.1 düzeyinde engellendiği tespit edilmiştir [19]. Erper ve ark. [2019], disodyum oktaborat tetrahidrat (etidot-67) ve sodyum tetraborat dekahidrat (boraks dekahidrat)'ın P. expansum'un misel gelişmesini, spor çimlenmesini ve çim tüpü uzamasını güçlü bir şekilde engellediğini, bu etkinin tuzların artan konsantrasyonları ile ilişkili olduğunu bulmuşlardır. Ayrıca tedavi edici uygulamalarda, her iki tuzun \%3.0 konsantrasyonunda elma meyveleri üzerindeki lezyon alanını kontrol uygulamasına göre sirasıyla \%92.8 ve \%78.9'a kadar, koruyucu uygulamalarda ise sırasıyla \%94.3 ve \%98.3'e kadar azalttı̆ğ $(P<0.05)$ belirlenmiştir.

Kırgızistan'da hasat sonu elma gibi depolanan önemli tarımsal ürünlerde görülen fungal hastalıkların mücadelesinde, özellikle fungisitlere alternatif olarak kullanılabilecek bor tuzlarının etkinliklerinin belirlenmesi üzerine yapılan bir çalışma bildiğimiz kadarıyla bulunmamaktadır. $\mathrm{Bu}$ çalışmada boraks (sodyum tetrborat)'ın B. cinerea'nın misel gelişimi, spor çimlenmesi ve çim tüp uzamasına karşı etkileri ile fungitoksik etkileri in vitro'da belirlenmiştir. Ayrıca, elma meyveleri üzerinde kurşuni küf gelişimi üzerinde boraksın koruyucu ve tedavi edici etkileri de değerlendirilmiştir.

\section{Materyal ve Metot}

\section{Fungal İzolat}

Çalışmada kullanılan B. cinerea izolatı Kırgızistan Türkiye Manas Üniversitesi, Ziraat Fakültesi, Fitopatoloji laboratuvarındaki fungal kültür koleksiyonundan temin edilmiştir. Çalışmaya başlamadan önce, patates dekstroz agar (PDA; Merck Ltd., Darmstadt, Germany) besi ortamında geliştirilen kültürden hazırlanan inokulum $\left(1 \times 10^{5}{\left.\text { konidi } \mathrm{mL}^{-1}\right)}^{-1}\right.$ sağlıklı elma meyve (cv. Grany Smith)'lerine bulaştırılarak izolatın virülensliği doğrulanmıştır. İzolat gelecek çalışmalarda kullanmak için PDA içeren eğik tüplerde $+4^{\circ} \mathrm{C}$ 'de saklanmıştır. 


\section{Bor tuzu}

Çalışmada kullanılan boraks [sodyum tetraborat $\left(\mathrm{Na}_{2} \mathrm{~B}_{4} \mathrm{O}_{7}\right)$ ] Türkiye Eti Maden İşletmeleri Genel Müdürlüğü’nden temin edilmiştir.

\section{Misel gelişimi üzerine boraksın etkisi}

Boraksın B. cinerea'nın misel gelişimi üzerine etkisi Türkkan ve Erper [7]'in metoduna göre değerlendirilmiştir. Çalışmada kullanılan boraksın 7 farklı konsantrasyon $(\% 0.0312$, $0.0625,0.125,0.25,0.5,1.0$ ve 2.0 , w/v)'u sterilize edilmiş ve $50-55^{\circ} \mathrm{C}$ 'deki PDA besin ortamına eklenmiştir. Boraksın tüm besin ortamına homojen bir şekilde karışması için magnetik karıştırıcı kullanılmış ve farklı konsantrasyonları içeren PDA besin ortamı, steril Petri kaplarına (6 cm çaplı) $10 \mathrm{ml}$ olacak şekilde dökülmüş ve her bir konsantrasyonun pH'sı ölçülmüştür. Daha sonra PDA besin ortamında geliştirilmiş 5-7 günlük fungus kültüründen alınan $4 \mathrm{~mm}$ çaplı agar diskleri Petri kaplarına konmuş ve streç film ile çevrildikten sonra $20 \pm 1^{\circ} \mathrm{C}$ 'deki inkübatör (TK 252, Nüve, Türkiye)'de inkübasyona bırakılmıştır. Aynı şartlarda inkübe edilen ve herhangi bir kimyasal uygulanmamış kontrol grubu Petri kaplarındaki fungusun misel gelişimi günlük olarak takip edilmiş ve kenara temas etmeden önce kontrol ve tuz konsantrasyonlarını içeren kaplardaki fungusun en uzun ve en kısa radyal gelişimleri ölçülmüştür. Fungusun misel gelişiminin engellenmesi MGE $(\%)=($ kontrol Petri kaplarındaki fungal gelişme - tuz eklenmiş Petri kaplarındaki fungal gelişme / kontrol Petri kaplarındaki fungal gelişme) $\times$ 100 formülü kullanılarak hesaplanmıştır [12]. Deneme tuzun her bir konsantrasyonu için üç tekerrürlü olacak şekilde iki defa yapılmıştır [25].

\section{Konidi çimlenmesi ve çim tüp uzunluğu üzerine boraksın etkisi}

Botrytis cinerea izolatı PDA besin ortamında $20 \pm 1^{\circ} \mathrm{C}$ 'de 5-7 gün geliştirilmiş, daha sonra üzerine steril saf su eklenmiş, steril bistirü yardımıyla konidiler suya geçirilmiş ve elde edilen süspansiyon 2 kat steril tülbentten geçirilmiştir. Süspansiyondaki konidiler Thoma lamı (hemocytometre; Marienfeld; Germany) kullanılarak konsantrasyonu $1 \times 10^{5}$ konidi $\mathrm{mL}^{-1}$ ye ayarlanmıştır. Boraksın 7 farklı konsantrasyonu (\%0.0312, 0.0625, 0.125, 0.25, 0.5, 1.0 ve 2.0, w/v) PDA'ya eklenmiş ve $6 \mathrm{~cm}$ çaplı Petri kaplarına dökülmüştür. Fungusun spor süspansiyonu $(30 \mu \mathrm{L})$ boraks eklenmiş ve eklenmemiş (kontrol) her kaba, steril cam baget ile yayılmıştır. Petri kapları $20 \pm 1^{\circ} \mathrm{C}$ de 24 saat inkübasyona bırakılmış ve konidi çimlenme oranı (\%), her konsantrasyonda 400 konidi olmak üzere, Euromex Delphi-X Observer (Arnhem, Holland) model mikroskopta 400× büyütmede 
belirlenmiştir. İncelenen konidiler kendi büyüklüğü kadar çim tüpü oluşturmuş ise çimlenmiş olarak değerlendirilmiştir [6].

Ayrıca boraksın test edilen her konsantrasyonun çim tüpü uzaması üzerine etkisinin belirlenmesinde aynı kaplardaki 50 konidinin çim tüpü uzunlukları oküler mikrometre yardımıyla ölçülmüştür. Çim tüp uzunluğunun engellenmesi, ÇTUE $(\%)=($ kontrol Petri kaplarındaki çim tüpü uzunluğu - tuz eklenmiş Petri kaplarındaki çim tüpü uzunluğu) / kontrol Petri kaplarındaki çim tüpü uzunluğu) x 100 formülüne göre hesaplanmıştır. Deneme tuzun her bir konsantrasyonu için üç tekerrürlü olacak şekilde iki defa yapılmıştır [6].

\section{Misel gelişimi üzerine pH'nın etkisi}

Fungusun geliştirileceği PDA besi ortamı steril edildikten sonra 50-55 C'ye kadar soğutulmuş ve besi ortamının pH'sı $1 \mathrm{~N}$ sodyum hikroksit $(\mathrm{NaOH})$ ve hidroklorik asit (HCl) ile 2.0, 3.0, 4.0, 5.0, 6.0, 7.0, 8.0, 9.0, 10.0, 11.0, 12.0 ve 13.0'a ayarlanmıştır. Daha sonra 6 cm çaplı Petri kaplarına dökülmüş ve bu kaplara PDA'da geliştirilmiş 5-7 günlük fungal kültürden alınan $4 \mathrm{~mm}$ çaplı agar diskleri inokule edilmiştir. Petri kapları $20 \pm 1^{\circ} \mathrm{C}$ 'de inkübasyona bırakılmış, gelişmeleri günlük olarak takip edilmiş ve farklı pH'ları içeren kaplardaki fungusun en kısa ve en uzun radyal gelişmeleri ölçülmüştür. Deneme tuzun her bir konsantrasyonu için üç tekerrürlü olacak şekilde iki defa yapılmıştır [24].

\section{Boraksın toksik etkisi}

Fungusun misel gelişimini $\% 50$ engelleyen konsantrasyon $\left(\mathrm{EC}_{50}\right)$ değeri IBM SPSS İstatistik paket programı kullanılarak probit analizi ile belirlenmiştir. Ayrıca misel gelişimini tamamen engelleyen en küçük konsantrasyon $(\mathrm{MIC}=$ minimum engelleyici konsantrasyon) da belirlenmiştir [24]. Bunun yanında boraksın fungisidal/fungitoksik etkilerinin belirlenmesi için Thompson [22] ve Tripathi ve ark. [23]'nin metodları kullanılmıştır. Buna göre tuz konsantrasyonunu içeren Petri kaplarında gelişme göstermeyen fungal diskler alınarak, taze PDA içeren kaplara tekrar aşılanmış ve $20 \pm 1^{\circ} \mathrm{C}$ 'de 9 gün boyunca takip edilmiştir. Bu süreçte fungal disklerde hiç bir gelişme gözlenmeyen konsantrasyon minimum fungisidal konsantrasyon (MFC) olarak değerlendirilmiştir. 


\section{Boraksın koruyucu ve tedavi edici etkileri}

Boraksın 5 farkl1 konsantrasyonu (\%1.0, 1.5, 2.0, 2.5 ve 3.0, w/v)'nun B. cinerea'ya karş1 koruyucu ve tedavi edici etkileri elma meyveleri üzerinde belirlenmiştir.

Koruyucu uygulamalar için, kullanılan sağlıklı elma (cv. Grany Smith) meyveleri musluk suyu altında yıkanmış ve steril kabin içinde kurumaya bırakılmıştır. Yüzeysel dezenfeksiyon amaciyla meyveler \%1'lik NaOCl'de $3 \mathrm{dk}$ tutulmuş ve 2 kez steril saf sudan geçirilmiş ve kurutulduktan sonra dezenfekte edilmiş plastik viyollere yerleştirilmiştir. Elmaların ekvator bölgesine karşılıklı olarak $3 \mathrm{~mm}$ çaplı steril bir tel yardımıyla 3-4 mm derinlikte iki adet yara açılmış ve meyveler steril kabin içinde iki saat tutulmuştur. Daha sonra bu yaralara hazırlanan tuz konsantrasyonlarından alınan 25 $\mu$ L'lik miktar mikropipetle yaralara uygulanmış ve bundan 2 saat sonra da $25 \mu \mathrm{L}$ 'lik $\% 0.03$ 'lük Tween 20 içeren $1 \times 10^{5}$ konidi $\mathrm{mL}^{-1}$ spor süspansiyonu tuz uygulaması yapılmış yaralara eklenmiştir.

Boraksın tedavi edici etkisinin tespitinde ise, önce $25 \mu \mathrm{L}$ spor süspansiyonu $\left(1 \times 10^{5}\right.$ konidi $\mathrm{mL}^{-1}$ ) mikropipetle aynı şekilde meyve üzerinde açılan yaralara uygulanmış ve 24 saat inkübasyona bırakılmıştır. Bu süre sonunda yaralara aynı tuz konsantrasyonları $25 \mu \mathrm{L}$ olarak eklenmiştir. Her iki uygulamada negatif kontrol için meyvelerde açılan yaralara aynı miktarda \%0.03'lük Tween 20 içeren steril saf su, pozitif kontrol için ise aynı miktarda fungusun spor süspansiyonu uygulanmıştır. Uygulama görmüş elmalar plastik kaplara yerleştirilerek inkübatörde $20 \pm 1^{\circ} \mathrm{C}$ 'de inkübasyona bırakılmıştır. İnokülasyondan yedi gün sonra enfekteli meyveler üzerinde gelişen lezyon alanı belirlenmiştir. Bu amaçla lezyonlu alan üzerine yerleştirilen asetat kağıdına fungal gelişmenin sınırları çizilmiş ve bunlar 5 cm'lik bar olan beyaz A4 kağıtlarına aktarılmıştır. Bu çizimler Mustek 1200 UB Plus (Mustek Systems, Inc., Hsin Chu, Taiwan, PRC), masaüstü scanner ile taranmış ve Digimizer programı (Version 4.0.0.0 for Windows 2005-2011 MedCalc Software, Mariakerke, Belçika) ile yüzey alanları hesaplanmıştır. Denemeler üç tekerrürlü olarak yürütülmüş, her bir elma meyvesi bir tekerrür olarak kabul edilmiştir [26].

\section{İstatistik analiz}

Çalışmada elde edilen verilere IBM SPSS İstatistik programı (version 21, Property of SPSS, Inc.;IBM Company) kullanılarak ayrı ayrı tek yönlü varyans analizi (ANOVA) uygulanmış ve ortalamalar arasındaki önemli farklılıklar Tukey-HSD testi $(P<0.05)$ ile belirlenmiştir. 


\section{Bulgular}

In vitro uygulamalar $B$. cinerea'nın misel gelişimi üzerine boraksın farklı konsantrasyonlarının engelleyici etkileri arasında önemli farklılıklar olduğunu göstermiştir $(P<0.05)$. En düşük 2 konsantrasyon (\%0.0312 ve \%0.0625)'da herhangi bir engelleme görülmezken, \%0.125 ve üst dozlarda kullanılan tuz konsantrasyonları arttıkça patojenin misel gelişimi üzerindeki engelleyici etkilerinin de arttığı gözlenmiştir. Fungusun misel gelişimi üzerinde en yüksek iki konsantrasyon (\%1.0 ve \%2.0)'nun neden olduğu engellemenin diğer tüm konsantrasyonlardan istatistiksel olarak önemli ölçüde farklı olduğu tespit edilmiştir $(P<0.05)$. Ayrıca tuz konsantrasyonu arttıkça besi ortamının pH'sının arttığ 1 ve daha bazik hale geldiğgi, ancak bu artışın misel gelişimini engellemede çok önemli olmadığı görülmüştür (Tablo 1).

Tablo 1 Boraksın artan konsantrasyonlarının Botrytis cinerea'nın misel gelişimi, konidi çimlenmesi ve çim tüp uzunluğu üzerine engelleyici etkisi (\%)

Table 1 The inhibitory effect of increasing concentrations of borax on mycelial growth, conidial germination and germ tube elongation of Botrytis cinerea $(\%)$

\begin{tabular}{lcccc}
\hline \multirow{2}{*}{$\begin{array}{c}\text { Konsantrasyon } \\
(\%, \mathrm{w} / \mathrm{v})\end{array}$} & $\mathrm{pH}$ & Misel gelişimi & Konidi çimlenmesi & Çim tüp uzunluğu \\
\hline 0.0312 & 6.98 & $0.00 \mathrm{e}$ & $1.25 \mathrm{e}$ & $59.67 \mathrm{f}$ \\
0.0625 & 7.45 & $0.00 \mathrm{e}$ & $4.25 \mathrm{e}$ & $69.81 \mathrm{e}$ \\
0.125 & 7.95 & $17.86 \mathrm{~d}$ & $24.00 \mathrm{~d}$ & $73.70 \mathrm{~d}$ \\
0.25 & 8.46 & $57.14 \mathrm{c}$ & $40.50 \mathrm{c}$ & $80.88 \mathrm{c}$ \\
0.5 & 8.60 & $71.43 \mathrm{~b}$ & $61.00 \mathrm{~b}$ & $87.19 \mathrm{~b}$ \\
1.0 & 8.78 & $97.62 \mathrm{a}$ & $100.00 \mathrm{a}$ & $100.00 \mathrm{a}$ \\
2.0 & 9.04 & $100.00 \mathrm{a}$ & $100.00 \mathrm{a}$ & $100.00 \mathrm{a}$ \\
Kontrol & 5.70 & $0.00 \mathrm{e}$ & $0.00 \mathrm{e}$ & $0.00 \mathrm{~g}$ \\
\hline
\end{tabular}

*Aynı sütunda yer alan ve aynı harfle gösterilen ortalamalar arasında Tukey-HSD testine göre fark yoktur $(P<0.05)$.

Boraksın artan konsantrasyonları ile fungusun konidi çimlenmesi ve çim tüp uzunluğu arasında engelleme yönünden pozitif bir ilişki olduğu tespit edilmiştir. Boraksın en düşük 2 dozunda fungusun konidi çimlenmesi üzerine engelleme oranı oldukça düşük kalmış ve kontrol uygulaması ile istatistiki olarak aynı grupta yer almışlardır. Buna karşılık boraksın \%1.0 ve 2.0 konsantrasyonlarında konidi çimlenmesinin tamamen engellendiği ve bunun diğer konsantrasyonlara göre istatistiksel olarak önemli ölçüde farklı olduğu belirlenmiştir $(P<0.05)$ (Tablo 1). Bununla birlikte boraksa karşı B. cinerea'nın çim tüp uzamasının konidi çimlenmesine göre daha hassas olduğu, diğer bir ifade ile boraksın en 
düşük konsantrasyon (\%0.0312)'unda konidi çimlenmesin \%1.25 oranında, aynı konsantrasyonda çim tüp uzunluğunun ise yaklaşık \%60 oranında engellendiği tespit edilmiştir (Tablo 1). Çalışmada ayrıca fungusun misel gelişimi üzerine 12 farklı pH'nın etkisinin değiştiği görülmüştür. En düşük $\mathrm{pH}(\mathrm{pH} 2)$ 'da ve $\mathrm{pH}$ 10-13'de misel gelişiminin tamamen engellendiği, buna karşılık fungus için en uygun $\mathrm{pH}$ değerinin $\mathrm{pH}$ 5-6 arasında olduğu belirlenmiştir (Şekil 1).

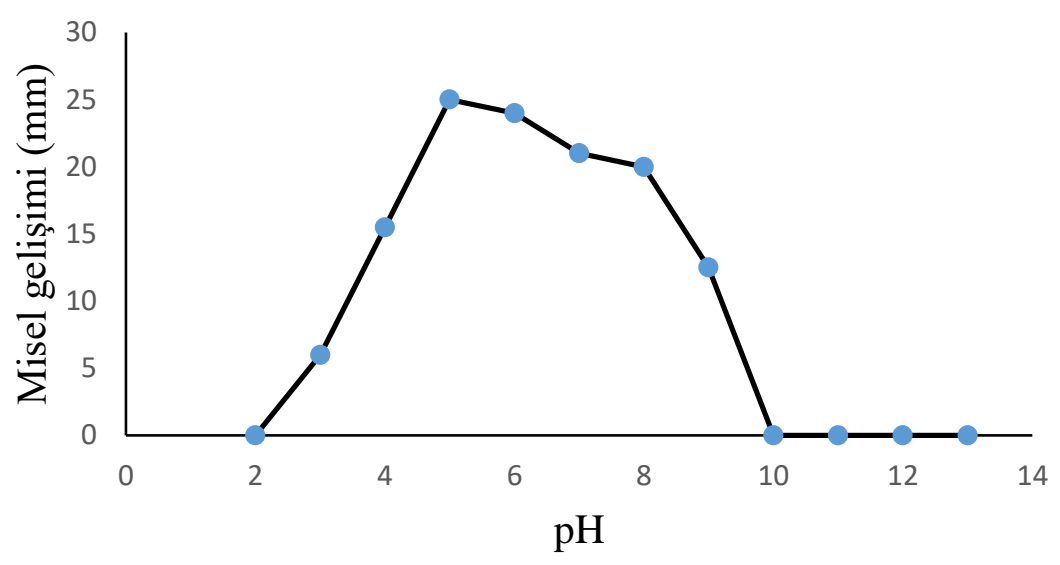

Şekil 1 Botrytis cinerea'nın misel gelişimi üzerine farklı $\mathrm{pH}$ 'ların etkisi Fig 1 Effect of different pHs on mycelial growth of Botrytis cinerea

Çalışmada test edilen boraksın $B$. cinerea'nın misel gelişimi üzerine toksik etkileri değerlendirildiğinde boraksın $\mathrm{EC}_{50}$ değerinin 0.263 (0.24-0.28) olduğu, bununla birlikte boraksın hem fungistatik konsantrasyon (MIC) değerinin, hem de fungisidal (fungitoksik) konsantrasyon (MFC) değerinin \%2.0 olduğu tespit edilmiştir.

Boraksın artan konsantrasyonlarının B. cinerea'ya karşı koruyucu ve tedavi edici etkilerinin belirlenmesi amacıyla yapılan in vivo testlerde, boraksın meyve üzerindeki lezyon gelişimini kontrole göre önemli oranda azalttığı belirlenmiştir $(P<0.05)$ (Tablo 2). Boraksın koruyucu uygulaması tedavi edici uygulamasına göre kurşuni küfü daha etkili bir şekilde kontrol etmiştir. Koruyucu uygulamanın en yüksek konsantrasyon (\%3.0)'unda, elmalardaki lezyon gelişiminin kontrole göre yaklaşık \%86 oranında engellendiği ve bunun istatistiki olarak önemli olduğu görülmüştür $(P<0.05)$ (Tablo 2). Tedavi edici uygulamada ise tuzun aynı konsantrasyondaki lezyon oluşumunu engelleme oranı \%63.16' da kalmıştır (Şekil 2). 
Tablo 2 Boraksın artan konsantrasyonlarının elmada kurşuni küf etmeni Botrytis cinerea'ya karşı koruyucu ve tedavi edici etkileri (in vivo)

Table 2 Protective and curative effects of increasing concentrations of borax against the grey mould agent Botrytis cinerea on apple (in vivo)

\begin{tabular}{ccc}
\hline \multirow{2}{*}{$\begin{array}{c}\text { Konsantrasyon } \\
(\%, \mathrm{w} / \mathrm{v})\end{array}$} & \multicolumn{2}{c}{ Engelleme (\%) } \\
\cline { 2 - 3 } 1.0 & $15.64 \mathrm{~d}$ & Tedavi edici uygulama \\
1.5 & $34.04 \mathrm{c}$ & $20.12 \mathrm{~d}$ \\
2.0 & $45.20 \mathrm{cb}$ & $30.18 \mathrm{c}$ \\
2.5 & $54.16 \mathrm{~b}$ & $38.91 \mathrm{bc}$ \\
3.0 & $85.69 \mathrm{a}$ & $45.36 \mathrm{~b}$ \\
Pozitif Kontrol & $0.00 \mathrm{e}$ & $63.16 \mathrm{a}$ \\
\hline
\end{tabular}

*Aynı sütunda yer alan ve aynı harfle gösterilen ortalamalar arasında Tukey-HSD testine göre fark yoktur $(P<0.05)$.

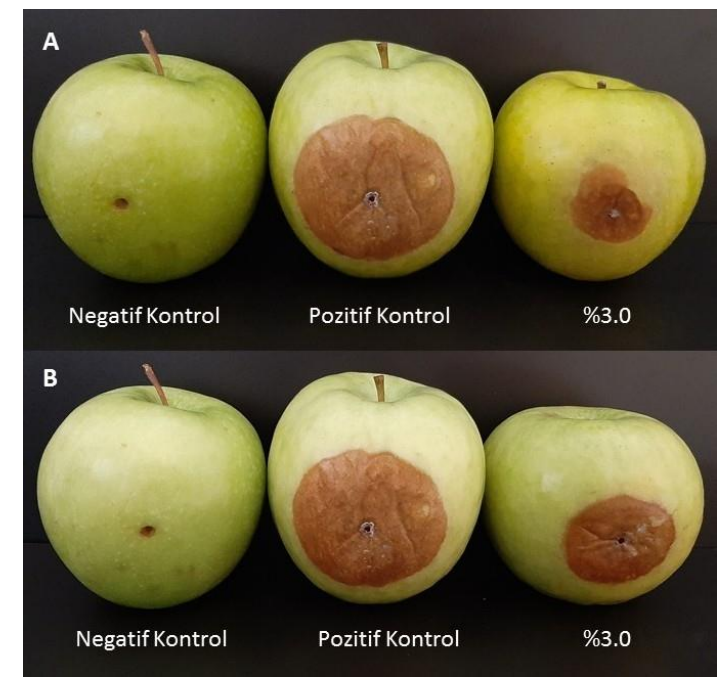

Şekil 2 Boraksın kurşuni küf etmeni Botrytis cinerea'ya karşı \%3.0'lık konsantrasyonda engelleyici etkisi, koruyucu uygulama (A), tedavi edici uygulama (B)

Fig 2 Inhibitory effect of borax against the grey mould agent Botrytis cinerea at a concentration of $3.0 \%$, protective application (A), curative application (B)

\section{Tartışma}

Bu çalışmada önemli bir bor bileşiği olan sodyum tetraborat (boraks)'ın B. cinerea'nın neden olduğu elmada kurşuni küf hastalığının kontrolünde etkili olduğu belirlenmiştir. Antifungal etkinin boraksın artan konsantrasyonları ile arttığı görülmüştür.

Bitkilerin ihtiyaç duyduğu bir mikro besin elementi olan bor, bitkilerin kök uçları gibi aktif olarak büyüyen kısımları ile çiçek gelişimi, yaprak, tomurcuk, meyve ve tohum oluşumunda oldukça öneme sahiptir [1]. Ayrıca borun bazı formları orman endüstrisinde 
ahşap malzemelerini bazı zararlı böcek ve funguslardan korumak amacıyla kullanılmış, yine sodyum tetraboratın iğne yapraklı orman ağaçlarında önemli patojenlerden bir olan Heterobasidion annosum'a karşı etkili olduğu tespit edilmiştir [9; 18]. Bunların yanında borun farklı formlarının önemli bazı bitki patojenlerine karşı da antifungal etki gösterdikleri yapılan farklı çalışmalarda tespit edilmiştir [17; 21; 3].

Çalışmada kullanılan boraksın konsantrasyonlarına bağlı olarak B. cinerea'nın misel gelişimi, konidi çimlenmesi ve çim tüp uzunluğu gelişiminin önemli oranda azaldığı ya da tamamen engellediği görülmüştür. Elde edilen bu sonuçlar borun farklı tuzlarının değişik patojenler üzerindeki antifungal etkilerinin tespiti amacıyla yapılan benzer çalışmalar ile uyumludur $[16 ; 3 ; 11 ; 19 ; 6 ; 28]$. Potasyum tetraboratın artan konsantrasyonlarının bağda kurşuni küf etmeni B. cinerea'nın misel gelişmesi, spor çimlenmesi ve çim tüp uzaması üzerinde engelleyici etkilerinin olduğu, bor tuzunun kontrol uygulamalarına göre $\% 0.1$ 'de konidi çimlenmesini ve $\% 0.05$ 'de ise çim tüp uzamasını önemli derecede azalttığı $(P<0.05), \% 1.0$ 'de misel gelişimini, \%0.5'de ise spor çimlenmesini ve çim tüp uzamasını tamamen engellendiği rapor edilmiştir [16]. Benzer olarak Cao ve ark. [3] potasyum tetraboratın konsantrasyonu arttıkça $P$. expansum'un misel gelişiminin azaldığını, yani düşük konsantrasyonlarda (\%0.01 ve $0.05, \mathrm{w} / \mathrm{v}$ ) misel gelişimi gözlenmesine rağmen, \%0.1'de \%10-15'e kadar, \%0.25' de ise tamamen engellemenin olduğunu tespit etmişlerdir. Yine aynı patojene karşı kullanılan etidot-67 ve boraks dekahidratın artan dozları ile engelleyici etkileri arasında pozitif bir ilişkinin olduğu, P. expansum'un misel gelişiminin $\% 0.25$ 'de, spor çimlenmesi ve çim tüp uzamasının ise \%0.125'de tamamen engellediği belirlenmiştir [6]. Yapılan başka bir çalışmada borik asitin 6 farklı konsantrasyonunun elmada mavi küf etmeni $P$. expansum'un misel gelişimi, konidi çimlenmesi ve çim tüp uzunluğu üzerine antifungal etkisinin olduğu, $\% 0.25$ ve üst dozlarında \%100 engellemenin olduğu tespit edilmiştir [28]. Patateslerde kuru çürüklük etmeni $F$. sulphureum'a karşı sodyum tetraborat ve potasyum tetraboratın konsantrasyonları arttıkça fungusun konidi çimlenmesinin ve misel gelişiminin azaldığı ve en yüksek konsantrasyon ( $20 \mathrm{~g} / \mathrm{L})$ 'da ise tamamen engellenmenin gerçekleştiği rapor edilmiştir [11].

Çalışmada kullanılan boraks (sodyum tetraborat) en düşük konsantrasyon hariç, diğer üst konsantrasyonlarda alkali pH (7.45-9.04) göstermiştir. Boraksın pH'sı genel olarak 7.0'dan büyük olduğundan, antifungal etkinin alkali pH'dan kaynaklanıp 
kaynaklanmadığı da bu çalışmada belirlenmiştir. Fungusun misel gelişimi üzerine tam engellemenin olduğu en üst konsantrasyon (\%2.0)'da pH 9.04 iken, $\mathrm{NaOH}$ ile pH 9.0'a ayarlanan PDA besi ortamında fungusun misel gelişimi gözlenmiş, $\mathrm{pH} 10$ ve üzerinde ise gelişme tamamen engellenmiştir. Elde ettiğimiz bu sonuç, fungusa karşı boraksın engelleyici etkisi üzerinde farklı pH'ların kısmen etkili olduğunu, diğer bazı organik ve inorganik tuzlar gibi bor bileşiklerinin pH'dan bağımsız olarak antifungal etki gösterdiğini ortaya koymuş olup, pH'nın engelleyici etkide küçük bir rolünün olduğunu bildiren önceki çalışmalarla da uyum içindedir [12; 13; 16; 24].

Bitki patojeni funguslara karşı farklı bor formlarının (bileşiklerinin), bazı organik ve inorganik tuzların bitki patojeni funguslara karşı toksik etkilerinin olduğu yapılan farklı çalışmalarda rapor edilmiştir. Kivide kurşuni küf etmeni B. cinerea'ya karşı kullanılan 6 farklı tuz arasında amonyum karbonat, amonyum bikarbonat ve sodyum karbonat tuzlarının $\mathrm{EC}_{50}$ değerinin $10 \mathrm{mM}$ düşük olduğu ve $\mathrm{MIC}$ değerlerinin sırasıyla 25, 10 ve $25 \mathrm{mM}$ olduğu rapor edilmiştir [26]. Etidot-67 ve boraks dekahidratın $P$. expansum'a karşı toksisitelerinin belirlenmesi için yapılan çalışmada $\mathrm{EC}_{50}$ değerlerinin sırasıyla 0.067 ve 0.071 olduğu belirlenmiş, minimum engelleyici konsantrasyon (MIC) değerleri \%0.25 iken, aynı tuzların minimum fungisidal konsantrasyon (MFC) değerleri \%1.0'dan büyük bulunmuştur [6]. Yapılan başka bir çalışmada aynı patojene karşı test edilen borik asitin EC $_{50}$ değeri $\% 0.09$, MIC ve MFC değerleri sirasıyla, $\% 0.25$ ve $>\% 2.0$ olarak belirlenmiştir [28]. Li ve ark. [11], sodyum tetraborat ve potasyum tetraboratın $F$. sulphureum'un misel gelişimi üzerinde $\mathrm{ED}_{50}$ değerlerini sırasıyla 2.8 ve $3.2 \mathrm{~g} \mathrm{~L}^{-1}$, konidi çimlenmesi üzerinde ise $\mathrm{ED}_{50}$ değerlerinin sirasıyla 2.1 ve $2.4 \mathrm{~g} \mathrm{~L}^{-1}$ olarak belirlemişlerdir. Çalışmada elde ettiğimiz sonuçlar daha önce yapılan çalışmalarla uyum içinde olup, boraksın B. cinerea'nın misel gelişimi üzerinde toksik etki gösterdiği ve $\mathrm{EC}_{50}$ değerinin 0.263 olduğu, ayrıca boraksın hem fungistatik konsantrasyon (MIC) değerinin hem de fungisidal (fungitoksik) konsantrasyon (MFC) değerinin \%2.0 olduğu tespit edilmiştir. Çalışmada test edilen boraksın in vitro koşullarda etkili olan konsantrasyonlarının, in vivo koşullarda yapılan hem koruyucu hem de tedavi edici uygulamalarda etkili olmadıkları görülmüştür. Boraksın en yüksek iki konsantrasyonunda (\%1.0 ve \%2.0) misel gelişimi, konidi çimlenmesi ve çim tüp uzaması \%97.62-100 oranında engellenirken, patojen inokulasyonunun 7. günü sonunda pozitif kontrol uygulamasına göre \%1.0 ve \%2.0 konsantrasyonlarda lezyon çapları sırasıyla, koruyucu 
uygulamada \%15.64 ve \%45.20, tedavi edici uygulamada ise $\% 20.12$ ve $\% 38.91$ oranlarında engelleme görülmüştür. En yüksek konsantrasyon (\%3.0)'da ise yaklaşık $\% 86$ ve \%63 oranında engellemenin olduğu tespit edilmiştir. Daha önce yapılan benzer çalışmaların sonuçları bulgularımızı destekler nitelikte olup, antifungal etkiye sahip tuz bileşiklerinin in vitro ve in vivo etkinlikleri arasında bir pozitif ilişkinin olmadığı rapor edilmiştir [6; 28]. Bu uyumsuzluklarda konukçu doku-tuz interaksiyonları ve bazı çevresel faktörlerin etkili olduğu belirtilmektedir [8].

Sonuç olarak, bu çalışma ile boraksın B. cinerea'nın neden olduğu elmada kurşuni küf hastalığının mücadelesinde sentetik fungisitlere alternatif olarak kullanılabileceği tespit edilmiştir. In vivo koşullarda boraksın \%3.0 konsantrasyonu uygulanan elma meyveleri üzerine herhangi bir fitotoksisite oluşmaması, bu tuzun hasat sonu hastalıklarına neden bitki patojenlerine karşı potansiyel olarak kullanılabileceğini göstermektedir. Boraksın fungusun hücre zarına verdiği zarar sonucunda sitoplazmik içeriğin dışarı çıkması ve sonuçta patojenin ölümüne neden olması şeklinde antifungal etkisinin olduğu bilinmektedir [16]. Bitkiler için gerekli bir mikro element olan borun farklı formlarının bitki patojeni fungus, bakteri, yabanc1 ot ve böceklerin mücadelesinde kullanılabilmektedir. Ayrıca başta elma olmak üzere hasat sonu depolanacak bazı ürünlerdeki fungal hastalıkların entegre mücadelesi için, boraks gibi antifungal etkiye sahip, bazı organik ve inorganik tuz birlikteliklerinin etkinliklerinin belirlenmesine yönelik çalışmalar yapılmalıdır.

\section{Kaynaklar}

1. Anonymous, https://agriculture.borax.com/boron-us-borax/what-is-boron/boron-in-plants, 2006. (Erişim tarihi: 05 Ekim, 2021).

2. Anonymous, Kırgızistan İstatistik Kurumları Yayınları http://www.stat.kg/ru/publications/osbore-urozhaya-selskohozyajstvennyh-kultur/, 2021. (Erişim tarihi: 08.10.2021)

3. Cao, B., et al., Boron improves the biocontrol activity of Cryptococcus laurentii against Penicillium expansum in jujube fruit. Postharvest Biology and Technology, 2012. 68: p. 16-21.

4. Conway, W.S., et al., Improving biocontrol using antagonist mixtures with heat and/or sodium bicarbonate to control postharvest decay of apple fruit Postharvest Biology Technology, 2005. 36: p. 235-244.

5. Elad, Y., et al., Botrytis spp. and diseases they cause in agricultural systems-an introduction. pp. 1-24. In 'Botrytis: biology, pathology and control'. (Eds Y. Elad, B. Williamson, P. Tudzynski, N. Delen), 2007. Springer

6. $\quad$ Erper, İ., et al., Elmada mavi küfe neden olan Penicillium expansum'a karşı bazı bor tuzlarının antifungal etkisi. Anadolu Journal of Agricultural Sciences, 2019. 34(3): p. 250-258.

7. FAOSTAT, Food and agriculture organization. The database of annual production. Statistical database, 2021. http:// faostat.fao.org. (Erişim tarihi: 10 Ekim 2021).

8. Hervieux, V., et al., Effect of organic and inorganic salts on the development of Helminthosporium solani, the causal agent of potato silver scurf. Plant Disease, 2002. 86: p. 1014-1018. 
9. Kartal, S.N., T. Yoshimura, and Y. Imamura, Decay and termite resistance of boron-treated and chemically modified wood by in situ co-polymerisation of allyl glycidyl ether (AGE) with methyl methacrylate (MMA). International Biodeterioration and Biodegradation, 2004. 53: p. 111-117.

10. Klein, J.D. and S. Lurie, Postharvest heat treatment and fruit quality. Postharvest News Information, 1991. 2: p. 15-19.

11. Li, Y., et al., Antifungal effect of borates against Fusarium sulphureum on potato tubers and its possible mechanisms of action. Postharvest Biology and Technology, 2012. 74: p. 55-61.

12. Mecteau, M.R., J. Arul, and R.J. Tweddell, Effect of organic and inorganic salts on the growth and development of Fusarium sambucinum, a causal agent of potato dry rot. Mycological Research, 2002.106: p. 688-696.

13. Nigro, F., et al., Control of table grape storage rots by pre-harvest applications of salts. Postharvest Biology and Technology, 2006. 42: p. 142-149.

14. Palou, L., et al., Effects of Xray irradiation and sodium carbonate treatments on postharvest Penicillium decay and quality attributes of clementine mandarins. Postharvest Biology and Technology, 2007. 46: p. 252-261.

15. Qin, G., et al., Crucial role of antioxidant proteins and hydrolytic enzymes in pathogenicity of Penicillium expansum. Molecular \& Cellular Proteomics, 2007. 6: p. 425-438.

16. Qin, G., et al., Inhibitory effect of boron against Botrytis cinerea on table grapes and its possible mechanisms of action. International Journal of Food Microbiology, 2010. 138: p. 145-150.

17. Rolshausen, P.E. and W.D. Gubler, Use of boron for the control of Eutypa dieback of grapevines. Plant Disease, 2005. 89: p. 734-738.

18. Schultz, M.E., J.R. Parmeter, and G.W. Slaughter, Long-term effect of treating true fir stumps with sodium tetraborate to control losses from Heterobasision annosum. Western Journal of Applied Forestry, 1992. 7: p. 29-31.

19. Shi, X., et al., Mechanism of antifungal action of borate against Colletotrichum gloeosporioides related to mitochondrial degradation in spores. Postharvest Biology and Technology, 2012. 67: p. 138-143.

20. Snowdon, A.L., A Colour Atlas of Postharvest Diseases and Disorders of Fruits and Vegetables: Vol. 1: General Introdiction and Fruits. 1990. Wolfe Scientific, London, Great Britain, 302 pp.

21. Thomidis, T. and E. Exadaktylou, Effect of boron on the development of brown rot (Monilinia laxa) on peaches. Crop Protection, 2010. 29: p. 572-576.

22. Thompson, D.P., Fungitoxic activity of essential oil componentson food storage fungi. Mycologia, 1989. 81: p. 151-153.

23. Tripathi, P., et al., Evaluation ofsome essential oils as botanical fungi toxicants in management of postharvest rotting of citrus fruits. World Journal Microbiology Biotechnology, 2004. 20: p. 317 321.

24. Türkkan, M. and İ. Erper, Evaluation of antifungal activity of sodium salts against onion basal rot caused by Fusarium oxysporum f.sp. cepae. Plant Protection Science, 2014. 50(1): p. 19-25.

25. Türkkan M. and İ. Erper, Inhibitory Influence of Organic and Inorganic Sodium Salts and Synthetic Fungicides Against Bean Root Rot Pathogens. Gesunde Pflanze, 201567: p. 83-94.

26. Türkkan, M., M. Özcan, and İ. Erper, Antifungal effect of carbonate and bicarbonate salts against Botrytis cinerea, the casual agent of grey mould of kiwifruit. Akademik Ziraat Dergisi, 2017. 6(2): p. 107-114.

27. Xuan, H., et al., Application of boron with calcium affects respiration and ATP/ADP ratio in 'Conference'pears during controlled atmosphere storage. The Journal of Horticultural Science and Biotechnology, 2005. 80(5): p. 633- 637.

28. Yıldırım, E., et al., Elmada mavi küfe neden olan Penicillium expansum'a karşı borik asitin antifungal etkisi. Harran Tarım ve Gıda Bilimleri Dergisi, 2020. 24(1): p. 64-72.

29. Zhang, J. and L.W. Timmer, Preharvest application of fungicides for postharvest disease control on early season tangerine hybrids in Florida. Crop Protection, 2007. 26: p. 886-893. 